\title{
New records of Ediacaran Acraman ejecta in drillholes from the Stuart Shelf and Officer Basin, South Australia
}

\author{
Andrew C. HILL ${ }^{1 *}$, Peter W. HAINES², Kathleen GREY², and Sebastian WILLMAN ${ }^{3}$ \\ ${ }^{1}$ Centro de Astrobiología (INTA-CSIC), Instituto Nacional de Técnica Aeroespacial, Ctra de Ajalvir, km 4, 28850 \\ Torrejón de Ardoz, Madrid, Spain \\ ${ }^{2}$ Geological Survey of Western Australia, 100 Plain Street, East Perth, WA 6000, Australia \\ ${ }^{3}$ Department of Earth Sciences, Paleobiology, Uppsala University, Villavägen 16, SE-752 36 Uppsala, Sweden \\ *Corresponding author. E-mail: hilla@inta.es
}

(Received 16 October 2006; revision accepted 29 April 2007)

\begin{abstract}
New occurrences of the Acraman impact ejecta layer were recently discovered in two South Australian drillholes, SCYW-79 1a (Stuart Shelf) and Munta 1 (Officer Basin) using lithostratigraphy, acritarch biostratigraphy, carbon isotope stratigraphy, and biomarker anomalies to predict the stratigraphic position. The ejecta layer is conspicuous because it consists of pink, sandsized, angular fragments of volcanic rock distributed along the bedding plane surface of green marine siltstone. In SCYW-79 1a it forms a layer $5 \mathrm{~mm}$ thick; in Munta 1 the ejecta layer is thin and discontinuous because of its distance ( $\sim 50 \mathrm{~km})$ from the impact structure. Palynological, biomarker, and carbon isotope anomalies can now be shown to coincide with the ejecta layer in SCYW-79 1a and Munta 1 suggesting the Acraman impact event may have had far reaching influences on the rapidly evolving Ediacaran biological and geochemical cycles.
\end{abstract}

\section{INTRODUCTION}

The Acraman impact structure (Williams 1986; Williams and Gostin 2005) lies within the early Mesoproterozoic Gawler Range Volcanics of the Gawler Craton in central South Australia (Fig. 1). The structure is deeply eroded such that the original crater diameter must be inferred and is controversial (ranging from $\sim 30$ to $>90 \mathrm{~km}$ ). A detailed discussion of crater size estimate using new data from ejecta thickness and distribution gives a diameter of 85-90 km (Williams and Wallace 2003), which agrees with the original estimate based on relict morphology (Williams 1986) and gravity and magnetic anomalies (Williams 1994a, 1994b; Williams et al. 1996). This makes Acraman one of the largest impact events recognized in Australia. Ejecta comprising sand to boulder-sized clasts of fractured and shocked felsic volcanic rock and rare impact spherules are preserved in relatively deep marine sediments of the Bunyeroo Formation (Adelaide Rift Complex) and Dey Dey Mudstone (Officer Basin) (Fig. 2) over an $550 \mathrm{~km}$ radius from the crater center (Fig. 1) (Gostin et al. 1986; Wallace et al. 1989; Hill et al. 2004; Williams and Gostin 2005).

The age of the Acraman impact event is uncertain and there are few geochronological constraints on the stratigraphic section that contains it. The underlying boundary for the Ediacaran Period GSSP has been defined in
Enorama Creek, Flinders Ranges, South Australia (Fig. 1) at the contact between glacial diamictite of the Elatina Formation and the base of the Nuccaleena Formation, the overlying “cap” carbonate (Fig. 2) (Knoll et al. 2004). This contact is present in SCYW-79 1a at $1010.7 \mathrm{~m}$, more than 600 $\mathrm{m}$ below the ejecta layer. However there is no direct geochronological constraint (U-Pb zircon date) for the Ediacaran global stratotype section and point (GSSP). Age estimates depend on correlation with other sections that probably correlate with the Elatina and Nuccaleena Formations and that have direct geochronological constraints. These include the boundary between diamictite and cap carbonate in sections in Namibia and China, which are both dated at 635 Ma (Hoffmann et al. 2004; Condon et al. 2005). Alternatively, the Elatina and Nuccaleena Formations could correlate with diamictite and a cap carbonate on King Island intruded by a sill dated at $575 \pm 4$ Ma and diamictite in Tasmania, which postdates a rhyodacite with a SHRIMP U-Pb age of $582 \pm 4 \mathrm{Ma}$, suggesting that the glaciation could be $\sim 580 \mathrm{Ma}$ (Calver et al. 2004). A single detrital zircon grain from the Bonney Sandstone, hundreds of metres above the Acraman ejecta layer and below the first Ediacara-type bilaterians, and which could record penecontemporaneous volcanism, was dated at $556 \pm 24 \mathrm{Ma}$ (Ireland et al. 1998). The Acraman impact is therefore no older 


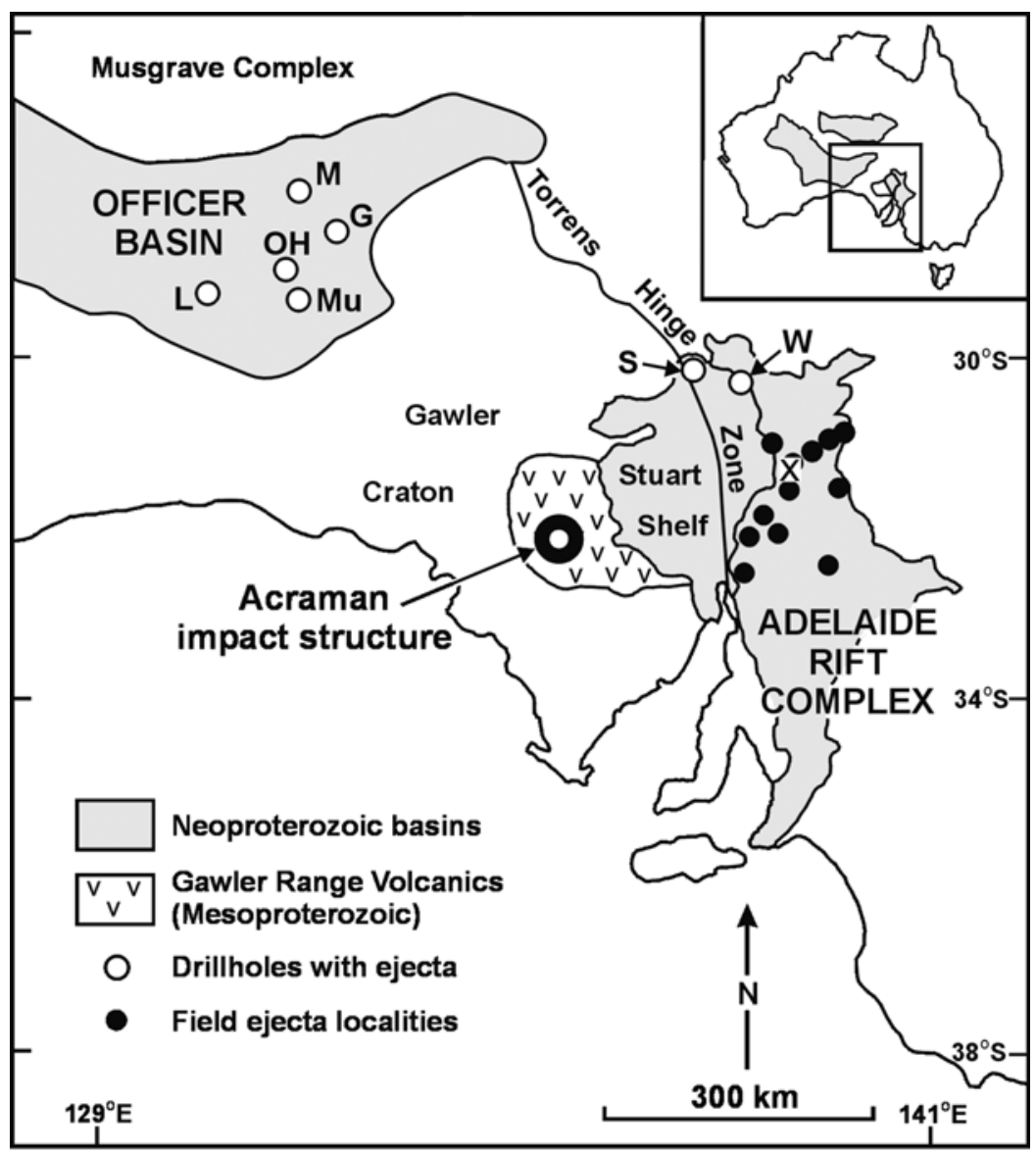

Fig. 1. Acraman impact structure and impact ejecta localities in outcrop (Adelaide Rift Complex) and drillholes (Officer Basin, Stuart Shelf and Torrens Hinge Zone) (after Wallace et al. 1996). X marks the location of the Ediacaran global stratotype section and point (GSSP). G: Giles 1; L: Lake Maurice West 1; M: Munta 1; Mu: Murnaroo 1; OH: Observatory Hill 1; S: SCYW-79 1a; W: WWD 1.

than 635 Ma and no younger than 556 Ma. Based on the chemostratigraphic time scale of Walter et al. (2000), and by intercalation of the impact event about halfway between the glaciation and the first appearance of the bilaterians, the estimated age of the Acraman impact event is either $\sim 625 \mathrm{Ma}$ (if the Elatina Formation correlates with the Ghaub Formation of Namibia and the Nantuo Formation of China) or 570 Ma (if the Elatina Formation is a correlative of the Croles Hill Diamictite of Tasmania), or between these ages.

Acraman was large enough to cause a global catastrophe (Toon et al. 1997; Williams and Wallace 2003), but the extent to which such bolide impacts can affect the biosphere and biogeochemical cycles on a regional or global scale is hard to ascertain. This is because a plethora of potentially concurrent processes (e.g., glaciation, sea level change, ocean stagnation, volcanism) make it difficult to untangle cause and effect (Twitchett 2006). In Australia, deposition appears to have taken place at a steady rate throughout the interval in question and no other major environmental perturbations are evident at the time of the Acraman impact that could account for some of the responses recorded. No mass extinction has been linked to the Acraman impact event, but this probably reflects the impoverished state of the biota immediately following glaciation. In Australia, there is an evolutionary diversification of large complex acritarchs (acanthomorphs, probable phytoplanktonic green algae [Marshall et al. 2005]) just above the ejecta layer (Grey et al. 2003; Grey 2005; Willman et al. 2006). Several of the taxa recorded in Australia are also known from Siberia (Moczydłowska et al. 1993), China (Zhang et al. 1998; Yuan and Hofmann 1998), and the East European Platform (Veis et al. 2006) at about the same stratigraphic level. In Australia, only a few taxa of simple, smooth-walled leiospheres (Figs. 3A and 3B) have been recorded after the glaciation. No evidence of species diversification has been observed, although numbers of specimens show a marked increase up to the time of the impact. Thereafter, the number of smooth-walled acritarchs and other biota, such as filaments and mat fragments, show a marked decline in numbers. By contrast, complex acritarchs (Fig. 3C-F), which may have been present in small numbers before the impact, and which show an ability to encyst and lie dormant until light, temperature, and nutrient conditions improve, probably survived the impact and subsequently diversified both in the number of species and number of 
Officer Basin

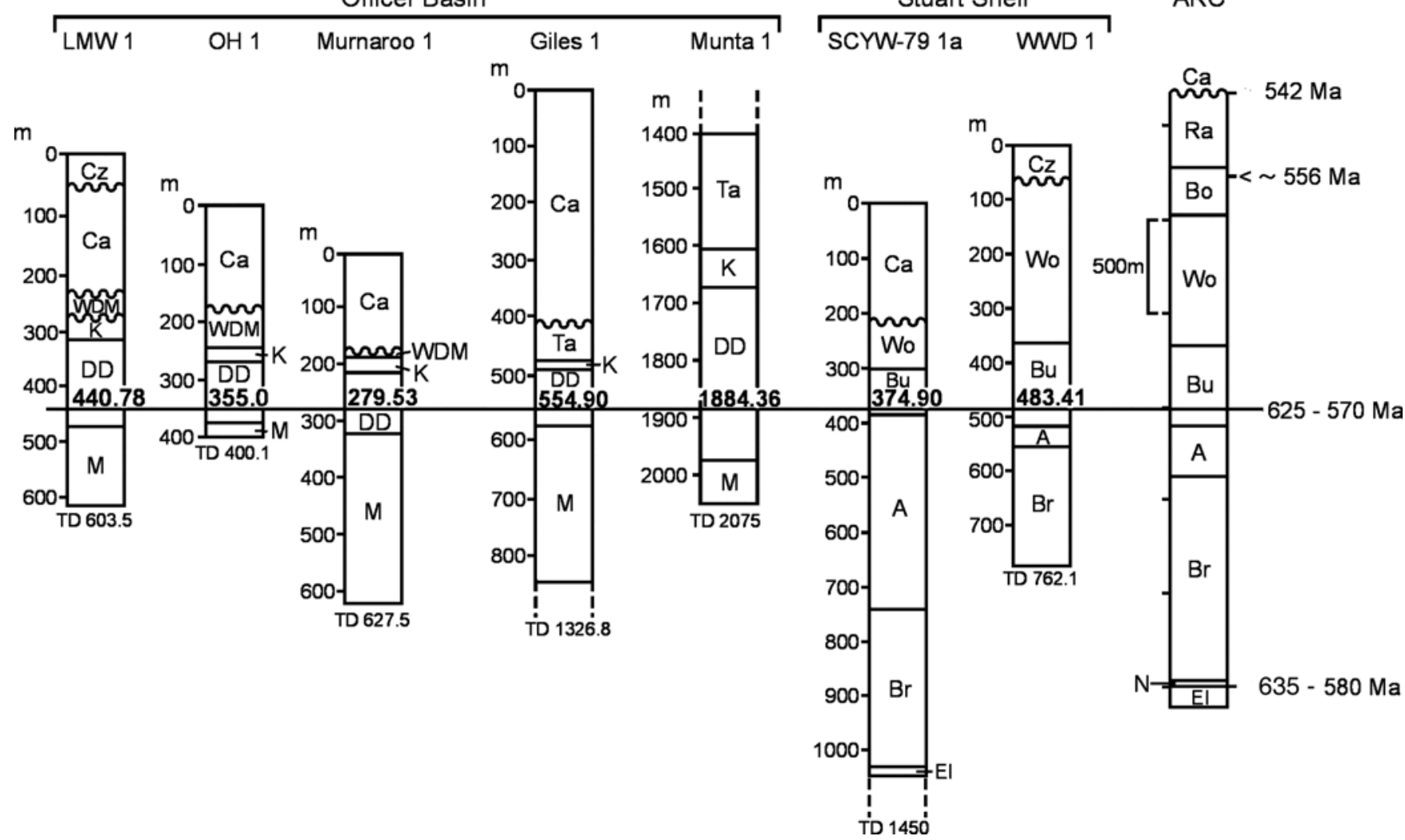

Fig. 2. Stratigraphy and correlation of drillholes containing the Acraman impact ejecta layer (shown as a continuous horizontal line through all the drillholes and including the depths where it is intercepted) and a generalized stratigraphic column for the Ediacaran Period in the Adelaide Rift Complex (ARC). On the ARC column are shown a 635-580 Ma age for the base of the Ediacaran Period, a less than 556 Ma age for the Bonney Sandstone (Ireland et al. 1998), an estimated age range of 625-570 Ma for the Acraman impact event (see explanation in text) and an 542 Ma age for the Ediacaran-Cambrian boundary (Gradstein et al. 2004). LMW 1: Lake Maurice West 1; OH 1: Observatory Hill 1; M: Murnaroo Formation; DD: Dey Dey Mudstone; K: Karlaya Limestone; WDM: Wilari Dolomite Member; Ta: Tanana Formation; Ca: Cambrian; Cz: Cenozoic; El: Elatina Formation; N: Nuccaleena Formation; Br: Brachina Formation; A: ABC Range Quartzite; Bu: Bunyeroo Formation; Wo: Wonoka Formation; Bo: Bonney Sandstone; Ra: Rawnsley Quartzite.

specimens (Grey 2005). Nearly fifty new taxa appeared within 5 or so million years (Grey 2005) exhibiting an evolutionary pattern reminiscent of recovery from mass extinction events (Twitchett 2006). The association between acritarch diversification and the position of the ejecta layer has now been recorded in SCYW-79 1a, a composite section based on WWD 1 and Mount James 1, Observatory Hill 1, Lake Maurice West 1, Munta 1, Murnaroo 1 and Giles 1 (Grey et al. 2003; Hill et al. 2004; Grey 2005; Willman et al. 2006 and unpublished data).

There are also carbon isotope anomalies in SCYW-79 1a, Observatory Hill 1 and Munta 1 (Calver and Lindsay 1998; Calver 2000; Grey et al. 2003; Hill et al. 2006) and biomarker anomalies (McKirdy et al. 2006; Webster et al. 2006) that coincide with the ejecta layer as confirmed by the new data presented in this paper. The carbon isotope changes are similar to those across the Permian-Triassic mass extinctionradiation event (Holser 1997) suggesting the Acraman impact event affected the long-term carbon cycle. There are two biomarker anomalies temporally linked to the Acraman impact event. The first is a eukaryotic signature shown by a marked increase in ethylcholestane abundance in many sediment samples that begins slightly below the body fossil appearance of acanthomorphs and persists for about 20 million years (McKirdy et al. 2006). The second is a bacterial signature expressed in the relative abundance of highly branched alkanes, which virtually disappear over $\sim 20 \mathrm{~m}$ of relatively deep-water mudstone in drillhole Munta 1 at the ejecta layer, reappearing $5 \mathrm{~m}$ below the onset of the eukaryotic anomaly (Webster et al. 2006). The latter anomaly probably reflects the initial collapse of the biosphere in response to the impact event and hence the food supply for bacterial heterotrophs, and the former marks the appearance and diversification of encysting chlorophyte algae

\section{CHARACTERISTICS OF THE ACRAMAN EJECTA LAYER}

The ejecta layer was first identified from a number of field locations in the Adelaide Rift Complex (Gostin et al. 1986) and 

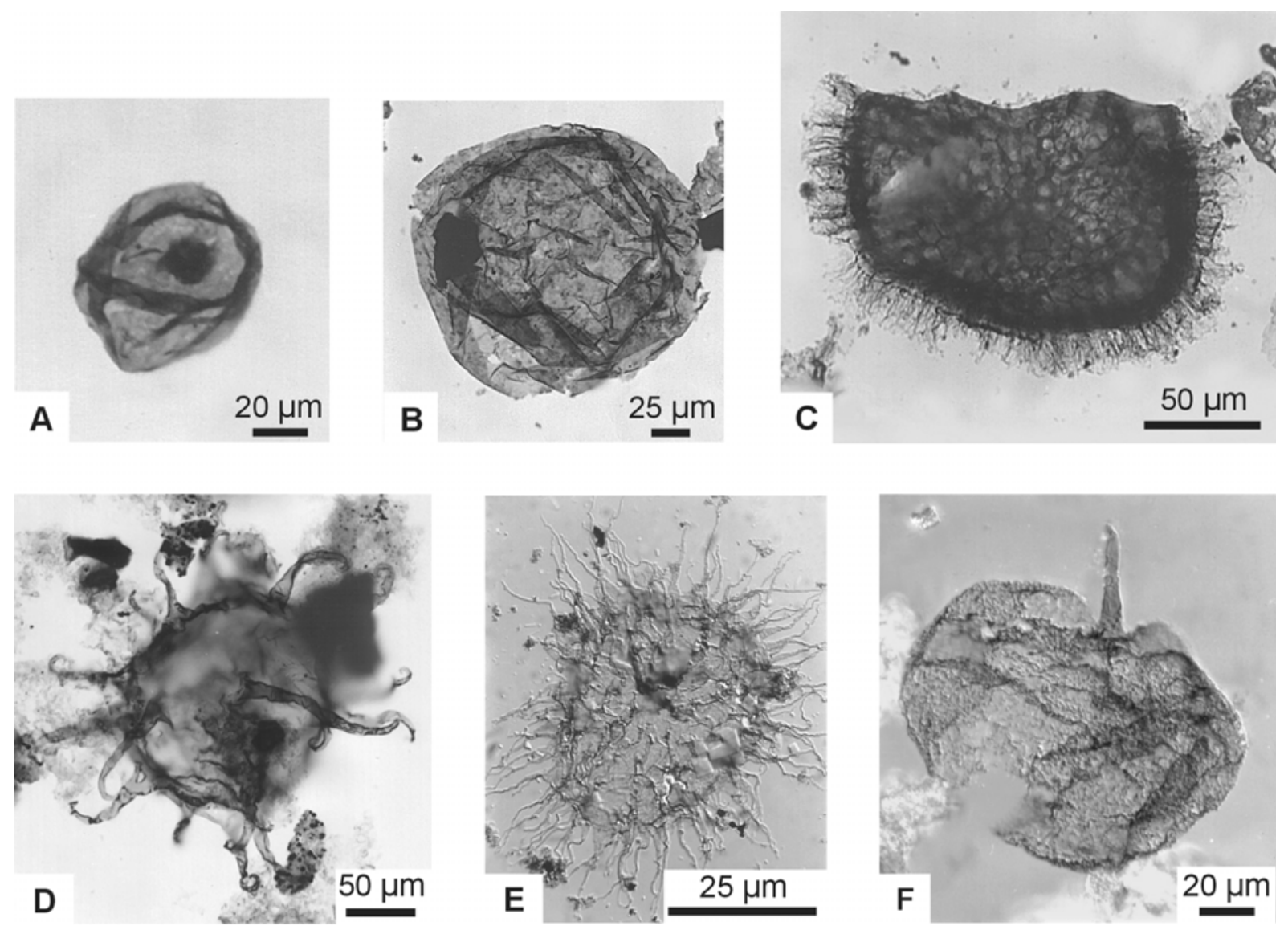

Fig. 3. Photomicrographs of acritarch species before (A, B) and after (C-F) the Acraman impact ejecta layer (Grey 2005). A: Leiosphaeridia crassa (Naumova 1949) Jankauskas in Jankauskas et al. 1989, and B: Leiosphaeridia tenuissima Eisenack 1958, are typical species of the Ediacaran Leiosphere Palynoflora (ELP). C-F are typical species from each of the four zones of the Ediacaran Complex Acanthomorph Palynoflora (ECAP). C: Appendisphaera barbata (Grey 2005), broken specimen but with well preserved ornament; D: Tanarium conoideum (Kolosova 1991 emend. Moczydłowska et al. 1993); E, Tanarium pycnacanthum (Grey 2005); F, Ceratosphaeridium mirabile (Grey 2005).

subsequently recognized in drill core in WWD 1 from the Adelaide Rift Complex and in drillholes Lake Maurice West 1 and Observatory Hill 1 from the Officer Basin (Wallace et al. 1989, 1990). Evidence for the presence of the layer consisted of: (1) the abundance of red, angular acid volcanic clasts; (2) the similarity of clast lithologies with those at the Acraman impact site and field localities in the Adelaide Rift Complex; (3) the presence of planar deformation features (PDFs) in quartz together with other shocked minerals; and (4) the presence of an Ir anomaly similar to those found in the Adelaide Rift Complex (Gostin et al. 1989). In both outcrop and drillholes there is commonly a lower, primary ejecta layer and one or two thinner ejecta layers above this that have been interpreted as reworked, possibly by associated tsunami effects (Wallace et al. 1996).

\section{ACRAMAN EJECTA IN DRILLHOLE SCYW-79 1a}

SCYW-79 1a, situated on the Stuart Shelf of the Adelaide Rift Complex (Fig. 1) $\left(30^{\circ} 07^{\prime} 30^{\prime \prime} \mathrm{S}, 137^{\circ} 09^{\prime} 24^{\prime \prime} \mathrm{E}\right)$, penetrated the Bunyeroo Formation between 301.0 and $385.0 \mathrm{~m}$ (Fig. 2). The depth of the ejecta layer was predicted from lithostratigraphy, acritarch biostratigraphy, and the change from fractured to non-fractured zircon crystals in palynological residues (Hill et al. 2004). The core is fragmented, so the ejecta is not seen in vertical section in the core tray, but can be observed on broken core surfaces as scattered grains. What is interpreted as the primary ejecta layer was discovered at $374.90 \mathrm{~m}$ where it is consists of pink sand-sized clasts in a band of green dolomitic siltstone about $5 \mathrm{~mm}$ thick (Fig. 4). A similar layer of clasts also in a green dolomitic band is present $20 \mathrm{~cm}$ above at $374.70 \mathrm{~m}$. The surrounding lithology is massive red-brown siltstone.

In thin section the lower and presumed primary ejecta horizon contains sand-sized angular clasts concentrated in three closely spaced millimeter-thick lamina with similar clasts scattered in the enclosing green dolomitic siltstone (Fig. 5). The clasts comprise hematitically altered plagioclase, K-feldspar and felsic volcanic rock fragments. Quartz, mafic grains altered to bright green chlorite, chert and 

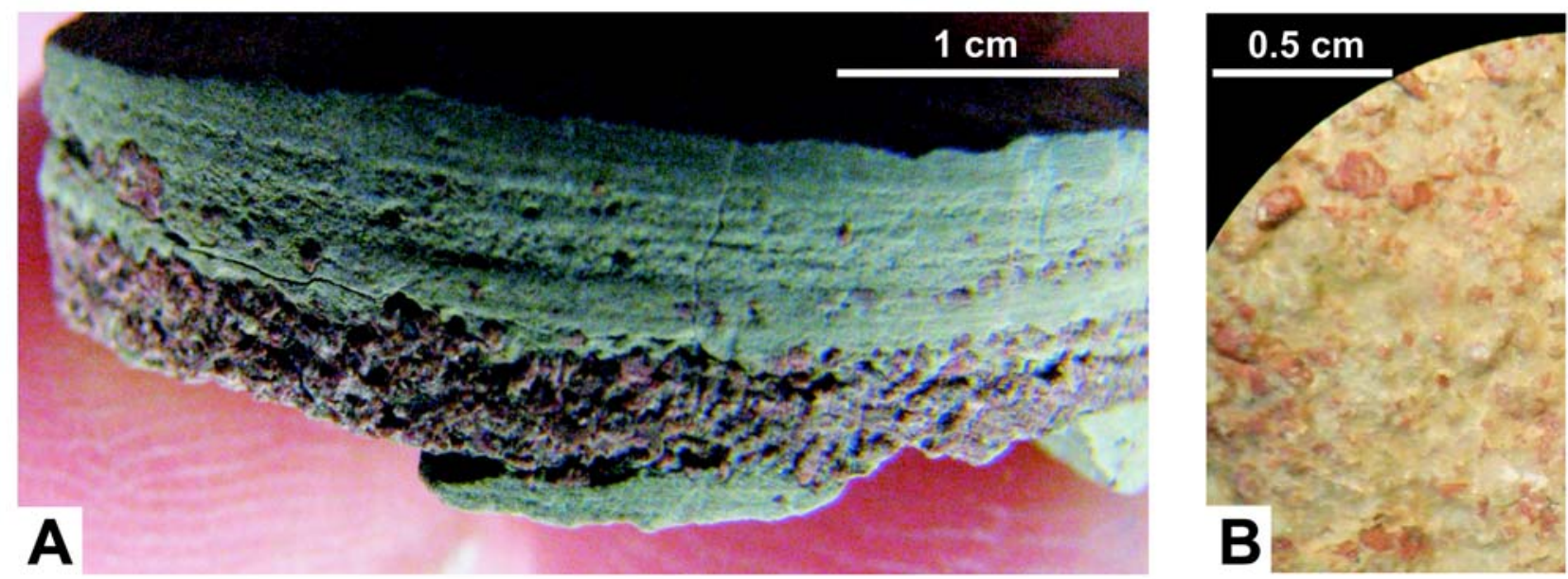

Fig. 4. a) Side-on photograph and b) plan view photograph (courtesy of S. George) of ejecta layer at a depth of $374.9 \mathrm{~m}$ in drillhole SCYW79 1a (PIRSA Repository \#1107114). Pink grains are acid volcanic rock fragments.

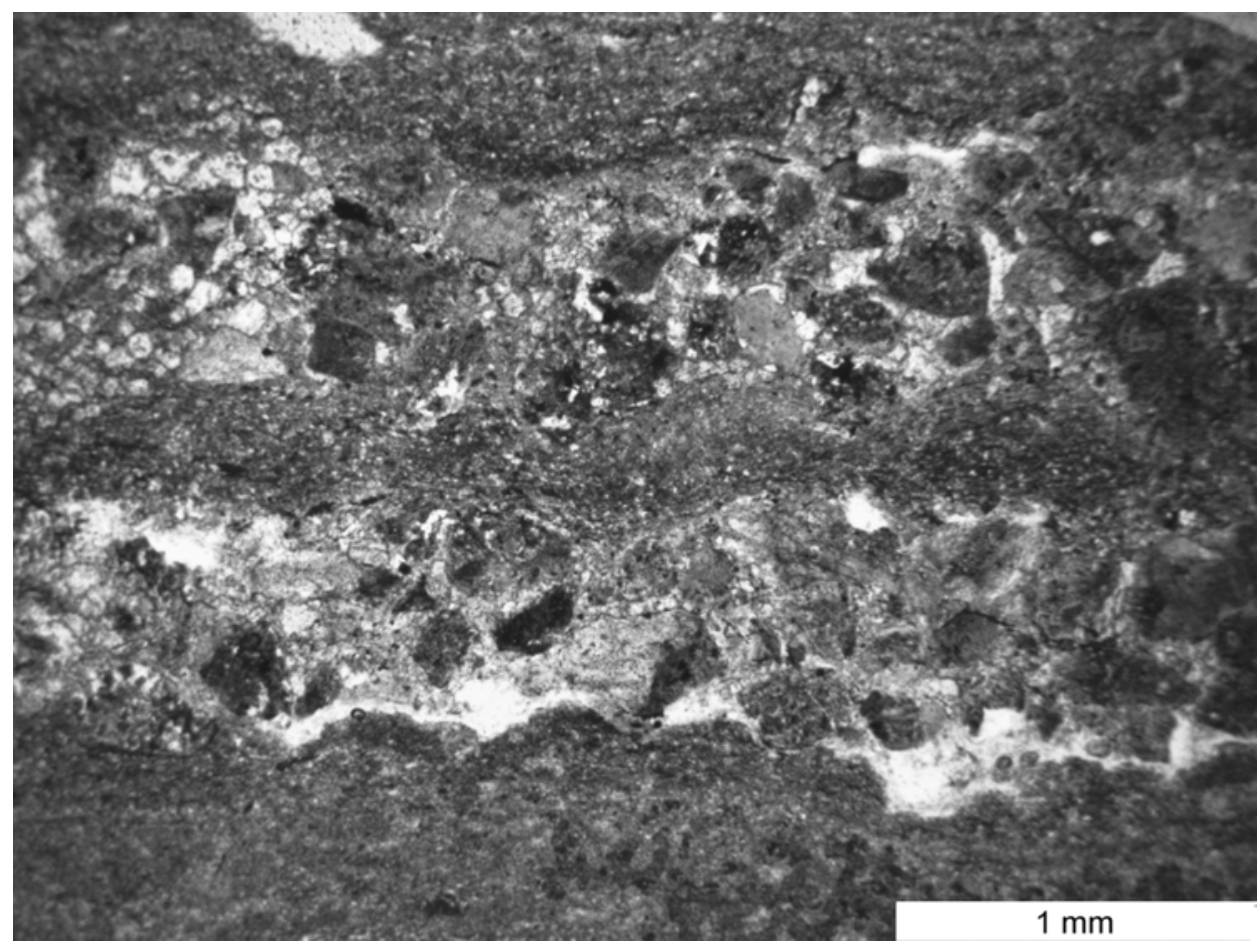

Fig. 5. Photomicrograph of ejecta layer at a depth of $374.9 \mathrm{~m}$ in drillhole SCYW-79 1a (PIRSA Repository \#1107114). The field of view shows two of the three lamina that make up the layer. Clasts are predominantly hematitically altered feldspar and felsic volcanic rock fragments (dark) partially cemented by diagenetic dolomite (pale). Plane polarized light.

opaque minerals form minor components. The average clast size is about $0.4 \mathrm{~mm}$ with a maximum of $0.8 \mathrm{~mm}$. Grains are angular to crudely rounded and typically equant. All clasts are consistent with derivation from the Gawler Range Volcanics and the assemblage is similar to that described from the Acraman ejecta layer elsewhere (Gostin and Zbik 1999; Wallace et al. 1996; Hill et al. 2004). Diagenetic dolomite is present in the interstices between volcanic clasts and in places may be replacing earlier mineral phases. The thin, presumably reworked, layer of grains at $374.70 \mathrm{~m}$ contains an identical assemblage of clasts and alteration products with similar size ranges (Fig. 6).

No shocked minerals were found in SCYW-79 1a but in thin sections from the Acraman layer in the Adelaide Rift Complex sand-sized quartz grains rarely show PDFs. The best shock evidence comes from large clasts of volcanics. There was also not enough material available for the possible detection of an Ir anomaly. Therefore, the evidence that this is 


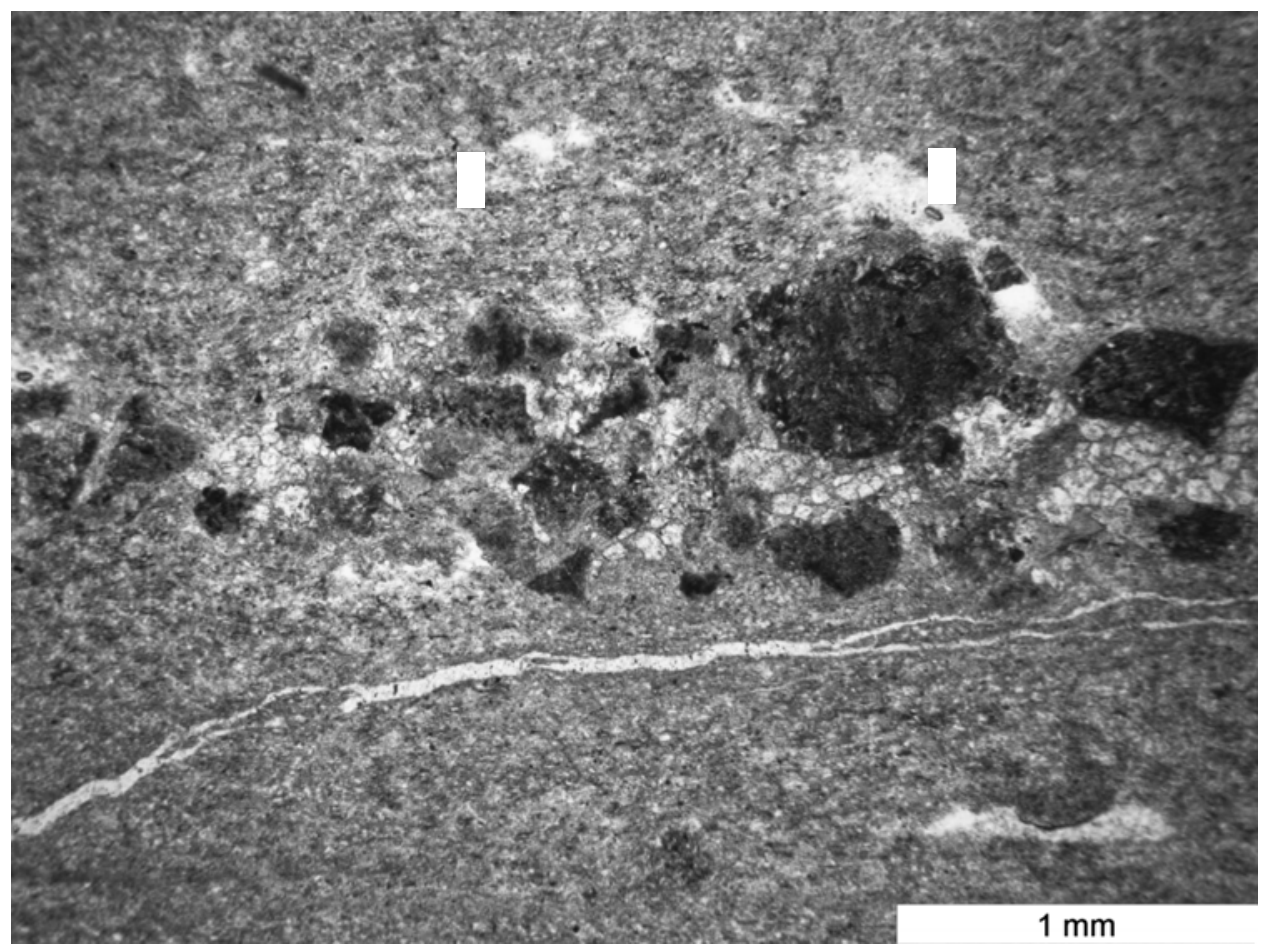

Fig. 6. Photomicrograph of reworked ejecta layer at a depth of $374.7 \mathrm{~m}$ in drillhole SCYW-79 1a (PIRSA Repository \#1107113). Hematitically altered feldspar and felsic volcanic rock fragments (dark) are locally surrounded by diagenetic dolomite (pale). Plane polarized light.

a record of the primary ejecta layer is equivocal. However, the presence of a second layer of ejecta at $374.70 \mathrm{~m}$ is consistent with occurrences in the Adelaide Rift Complex where there is a lower, primary ballistic ejecta layer often with larger rock fragments and a second, sand-sized ejecta layer separated from the primary layer by up to $15 \mathrm{~cm}$ of green siltstone. In SCYW-79 1a the angular nature of the labile feldspar and acid volcanic rock fragments and poor sorting all argue for minimal reworking in the upper layer. The small size of the angular fragments in the lower layer in SCYW-79 1a and the thinness of both the layers can be explained by evidence that shows the ejecta layer thins considerably to the north within the Adelaide Rift Complex and that the grain size of the primary ejecta layer varies dramatically along strike, from boulder-sized to sand-sized within only a few centimeters. For these reasons we suggest that the ejecta layer at $374.90 \mathrm{~m}$ is most likely to be primary.

\section{ACRAMAN EJECTA IN DRILLHOLE MUNTA 1}

Munta 1, situated in the eastern Officer Basin (Fig. 1) $\left(28^{\circ} 21^{\prime} 22^{\prime \prime} \mathrm{S}, 1^{\circ} 1^{\circ} 53^{\prime} 57^{\prime \prime} \mathrm{E}\right)$, penetrated the Dey Dey Mudstone between 1675.0 and $1973.0 \mathrm{~m}$ (Fig. 2). The approximate stratigraphic position of the Acraman ejecta layer was predicted using three independent lines of evidence: acritarch biostratigraphy, carbon isotope stratigraphy, and biomarker anomalies. At $1884.36 \mathrm{~m}$ (Fig. 7) a trail of pink, angular, sand-sized clasts are present on a bedding plane

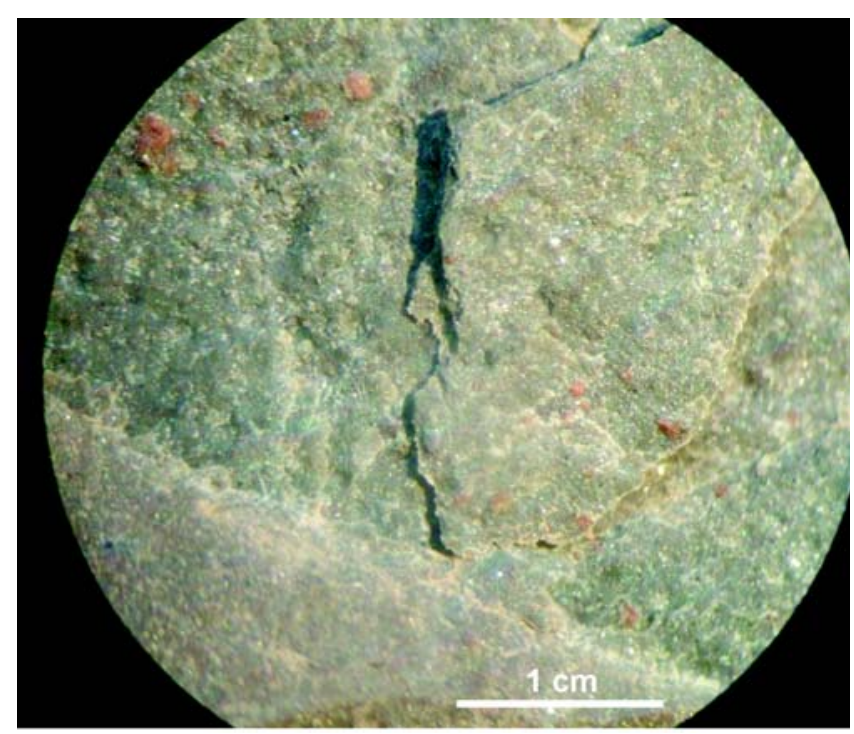

Fig. 7. Photograph of pink, acid volcanic rock fragments on green siltstone bedding plane at a depth of $1884.36 \mathrm{~m}$ in drillhole Munta 1 (PIRSA Repository \#1107115).

surface within a thin green band surrounded by otherwise red siltstone. In hand specimen the ejecta layer is similar to that in Giles 1 (Hill et al. 2004). In thin section (Fig. 8), the clasts are between 0.1 and $0.4 \mathrm{~mm}$ in diameter and form a discontinuous layer with grains spaced up to several millimeters apart. The grains comprise hematitically altered plagioclase, K-feldspar and felsic volcanic rock fragments typical of other 


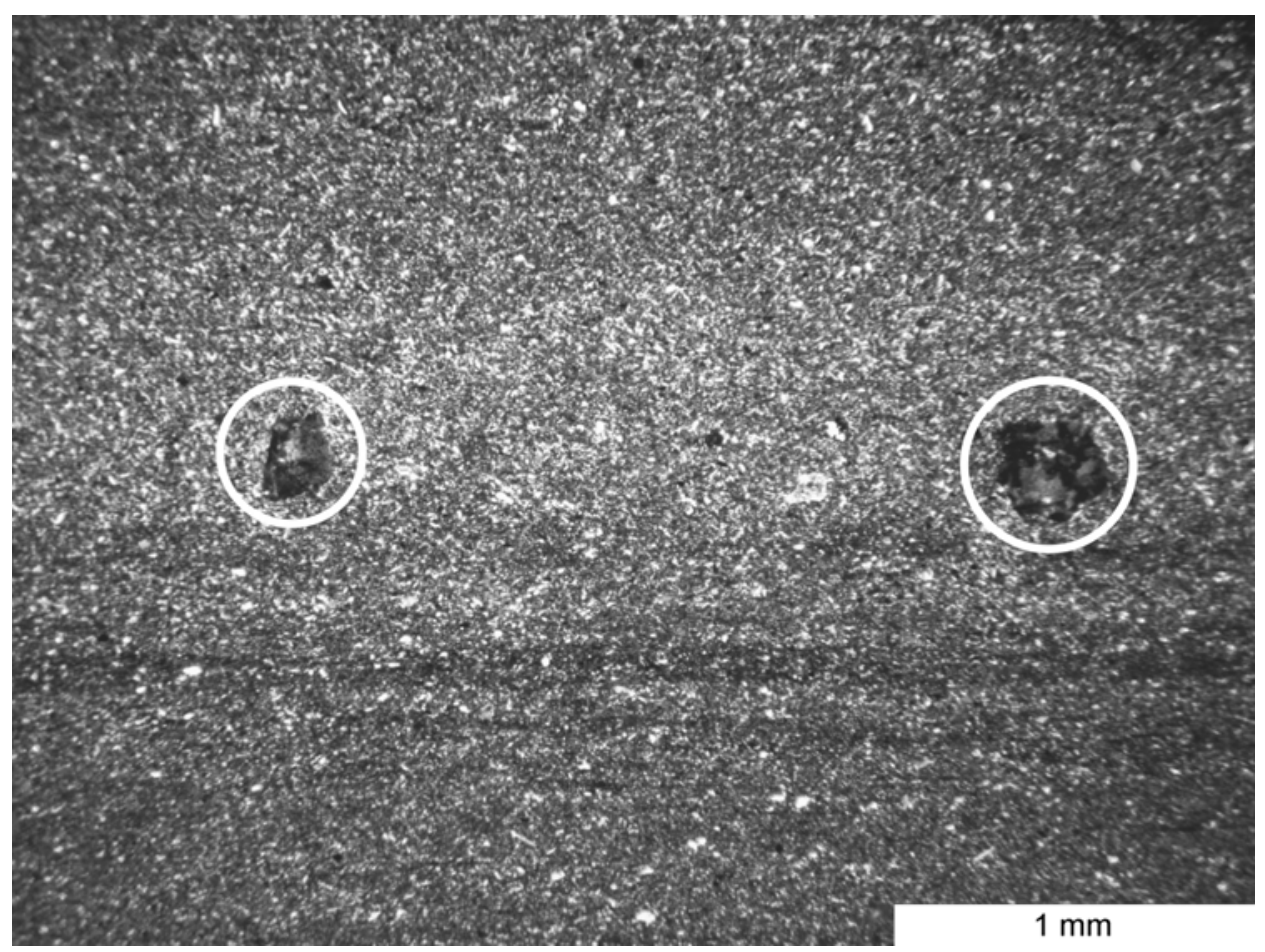

Fig. 8. Photomicrograph (crossed polars) of ejecta layer at a depth of 1884.36 in Munta 1 (PIRSA Repository \#1107115). The isolated clasts (inside white circles) comprise hematitically altered felsic volcanic rock fragments.

occurrences of Acraman ejecta. No definitive shock effects were observed but this is not surprising considering the small amount of material in thin section and that shock effects in quartz, such as PDFs, are rare in sand-sized debris in outcrop in the Adelaide Rift Complex. Any shock effects in feldspars have likely been destroyed by the intense diagenetic alteration. As for SCYW-79 1a there was too little material available for Ir analysis. Although the ejecta layer is thin and discontinuous, because of the distance from the crater, we suggest that this is the primary ejecta layer. It coincides with carbon isotope (Calver and Lindsay 1998; Hill et al. 2006) and biomarker anomalies (McKirdy et al. 2006; Webster et al. 2006), which strengthens this argument.

\section{CONCLUSIONS}

This report of Acraman impact ejecta, probably as the primary layer, in drillholes SCYW-79 1a from the Stuart Shelf and Munta 1 from the Officer Basin brings to seven the number of drillholes in which the ejecta layer has been identified. The relative position of the ejecta layer in other drillholes, acritarch biostratigraphy, carbon isotope stratigraphy, and biomarker anomalies narrowed down the interval in which it might be present and allowed for the discovery of its position in SCYW-79 1a and Munta 1. Its presence confirms correlations previously suggested by Wallace et al. (1989) to the Ediacaran section above the GSSP in the Adelaide Rift Complex and also confirms observations by Grey (2005) about the position of the ejecta layer relative to the first appearance of acanthomorph acritarchs. Since the ejecta layer was discovered in Murnaroo 1 (Hill et al. 2004), additional palynological studies have shown that the same biostratigraphic succession is present above the ejecta layer in that drillhole and that the first appearance of acanthomorph acritarchs has now been narrowed down to about $50 \mathrm{~m}$ above the Acraman ejecta layer (Willman et al. 2006). Ongoing acritarch biostratigraphy (Willman), carbon isotope stratigraphy (Hill), and biomarker research (L. J. Webster, University of Adelaide) in additional drillholes from the Officer Basin and Stuart Shelf aims to better determine what role the Acraman event played in Australian Ediacaran biotic and geochemical evolution. Once this is determined global correlations will be attempted to determine how far reaching the effects of the Acraman impact were.

Acknowledgments-We thank the Petroleum Branch of Primary Industry and Resources South Australia (PIRSA) and the PIRSA Core Library staff for access to and sampling from drillholes. ACH thanks the Australian Centre for Astrobiology and Macquarie University (Sydney, Australia) for initial financial support. Palynological processing was done by Laola Pty. Ltd. and Core Laboratories (Perth, Australia). Stable isotope analysis was undertaken in the laboratories of Environmental Isotopes Pty. Ltd. (Sydney, Australia). KG and PWH publish with the permission of the Director of the Geological Survey of Western Australia. SW acknowledges 
financial support from the grant Sederholms för utrikes resor, Uppsala University. Lynn Webster improved an early version of the manuscript. We thank H. Dypik and M. Wallace for their constructive reviews.

\section{Editorial Handling—Dr. Jens Ormö}

\section{REFERENCES}

Calver C. R. 2000. Isotope stratigraphy of the Ediacarian (Neoproterozoic III) of the Adelaide Rift Complex, South Australia, and the overprint of water column stratification. Precambrian Research 100:121-150.

Calver C. R. and Lindsay J. F. 1998. Ediacarian sequence and isotope stratigraphy of the Officer Basin, South Australia. Australian Journal of Earth Sciences 45:513-532.

Calver C. R., Black L. P., Everard J. L., and Seymour D. B. 2004. U$\mathrm{Pb}$ zircon age constraints on late Neoproterozoic glaciation in Tasmania. Geology 32:893-896.

Condon D., Zhu M., Bowring S. A., Wang W., Yang A., and Jin Y. 2005. U-Pb ages from the Doushantuo Formation, China. Science 308:95-98.

Eisenack A. 1958. Tasmanites Newton 1875 und Leiosphaeridia n.g. als Gattungen der Hystrichosphaeridea. Palaeontographica Abteilung A 110:1-19.

Gostin V. A. and Zbik M. 1999. Petrology and microstructure of distal impact ejecta from the Flinders Ranges, Australia. Meteoritics \& Planetary Science 34:587-592.

Gostin V. A., Haines P. W., Jenkins R. J. F., Compston W., and Williams I. S. 1986. Impact ejecta horizon within late Precambrian shales, Adelaide Geosyncline, South Australia. Science 233:198-200.

Gostin V. A., Keays R. R., and Wallace M. W. 1989. Iridium from the Acraman impact ejecta blanket, South Australia: Meteoroid impacts can produce iridium peaks. Nature 340:542-544.

Gradstein F. M., Ogg J. G., Smith A. G., Bleeker W., and Lourens A. J. 2004. A new geologic time scale, with special reference to Precambrian and Neogene. Episodes 27:83-100.

Grey K. 2005. Ediacaran palynology of Australia. Memoir of the Association Australasian Paleontologists 31:1-439.

Grey K., Walter M. R., and Calver C. R. 2003. Neoproterozoic biotic diversification: "Snowball Earth" or aftermath of the Acraman impact? Geology 31:459-462.

Hill A. C., Grey K., Gostin V. A., and Webster L. J. 2004. New records of Late Neoproterozoic Acraman ejecta in the Officer Basin. Australian Journal of Earth Sciences 51:47-51.

Hill A. C., Webster L. J., and McKirdy D. M. 2006. The Ediacaran Acraman impact event: Did it affect the long-term carbon cycle? (abstract). Geochimica et Cosmochimica Acta 70:A250.

Hoffmann K. H., Condon D. J., Bowring S. A., and Crowley J. L. 2004. A U-Pb zircon date from the Neoproterozoic Ghaub Formation, Namibia: Constraints on Marinoan glaciation. Geology 32:817-820.

Holser W. T. 1997. Geochemical events documented in inorganic carbon isotopes. Paleogeography Paleoclimatology Paleoecology 132:173-182.

Ireland T. R., Flöttmann T., Fanning C. M., Gibson G. M., and Preiss W. V. 1998. Development of the Early Paleozoic Pacific Margin of Gondwana from detrital zircon ages across the Delamerian Orogen. Geology 26:243-246.

Jankauskas T. V., Mikhailova N. S., and German T. N. 1989. Mikrofossilii Dokembriya SSSR. (Precambrian microfossils of the USSR). Leningrad: Trudy Institut Geologii i Geokhronologii Akademiya Nauk SSSR. 191 p. In Russian.

Knoll A. H., Walter M. R., Narbonne G. M., and Christie-Blick N. 2004. A new period for the geologic time scale. Science 305:621622.

Kolosova S. P. 1991. Pozdnedokembriyeskiye shipivatiye microfossilii vostoka Sibirskoi Platformi. Algologiya 39:53-59. In Russian.

Marshall C. P., Javaux E. P., Knoll A. H., and Walter M. R. 2005. Combined micro-Fourier transform infrared (FTIR) spectroscopy and micro-Raman spectroscopy of Proterozoic acritarchs: A new approach to paleobiology. Precambrian Research 138:208-224.

McKirdy D. M., Webster L. J., Arouri K. R., Grey K., and Gostin V. A. 2006. Contrasting sterane signatures in Neoproterozoic marine rocks of Australia before and after the Acraman asteroid impact. Organic Geochemistry 37:189-207.

Moczydłowska M., Vidal G., and Rudavskaya V. A. 1993. Neoproterozoic (Vendian) phytoplankton from the Siberian Platform, Yakutia. Paleontology 36:495-521.

Naumova S. N. 1949. Spory nizhnego kembriya (Spores of the Lower Cambrian). Izvestiya Akademiya Nauk SSSR. Seriya Geologicheskaya 4:49-56. In Russian.

Toon O. B., Zahnle K., Morrison D., Turco R. P., and Covey C. 1997. Environmental perturbations caused by the impacts of asteroids and comets. Reviews of Geophysics 35:41-78.

Twitchett R. J. 2006. The palaeoclimatology, palaeoecology and palaeoenvironmental analysis of mass extinction events. Paleogeography Paleoclimatology Paleoecology 232:190-213.

Veis A. F., Vorob'eva N. G., and Golubkova E.Yu. 2006. The early Vendian microfossils first found in the Russian Plate: Taxonomic composition and biostratigraphic significance. Stratigraphy and Geological Correlation 14(4):368-385 available at MAIK “Nauka/Interperiodica” (Russia). Original Russian text: Veis A. F., Vorob'eva N. G., and Golubkova E. Yu. 2006. Stratigrafiya, Geologicheskaya Korrelyatsiya 14(4):28-46.

Wallace M. W., Gostin V. A., and Keays R. R. 1989. Discovery of the Acraman impact ejecta blanket in the Officer Basin and its stratigraphic significance. Australian Journal of Earth Sciences 36:585-587.

Wallace M. W., Williams G. E., Gostin V. A., and Keays R. R. 1990. The Late Proterozoic Acraman impact-Towards an understanding of impact events in the sedimentary record. Mines and Energy Review South Australia 157:29-35.

Wallace M. W., Gostin V. A., and Keays R. R. 1996. Sedimentology of the Neoproterozoic Acraman impact-ejecta horizon, South Australia. AGSO Journal of Australian Geology and Geophysics 16:443-451.

Walter M. R., Veevers J. J., Calver C. R., Gorjan P., and Hill A. C. 2000. Dating the 840-544 Ma Neoproterozoic interval by isotopes of strontium, carbon, and sulfur in seawater, and some interpretative models. Precambrian Research 100:371433.

Webster L. J., McKirdy D. M., Arouri K. R., Grey K., and Gostin V. A. 2006. Highly branched $C_{3 n}$ alkanes and the Acraman impact event in Ediacaran deep marine shales of the eastern Officer Basin, South Australia (abstract). Combined National Conference of the Australian Organic Geochemists and the Natural Organic Matter Interest Group Conference, Program and Abstracts. p. 69.

Williams G. E. 1986. The Acraman impact structure; source of ejecta in late Precambrian shales, South Australia. Science 233:200203.

Williams G. E. 1994a. Acraman: A major impact structure from the Neoproterozoic of Australia. In Large meteorite impacts and 
planetary evolution, edited by Dressler B. O. Grieve R. A. F., and Sharpton V. L. GSA Special Paper 293. Boulder, Colorado: Geological Society of America. pp. 209-224.

Williams G. E. 1994b. Acraman: Australia’s largest meteorite impact structure. Proceedings of the Royal Society of Victoria 106:105127.

Williams G. E. and Gostin V. A. 2005. Acraman-Bunyeroo impact event (Ediacaran), South Australia, and environmental consequences: Twenty-five years on. Australian Journal of Earth Sciences 52:607-620.

Williams G. E. and Wallace M. W. 2003. The Acraman asteroid impact, South Australia: Magnitude and implications for the late Vendian environment. Journal of the Geological Society of London 160:545-554.

Williams, G. E., Schmidt, P. W., and Boyd, D. M. 1996. Magnetic signature and morphology of the Acraman impact structure, South Australia. AGSO Journal of Australian Geology and Geophysics 16:431-442.

Willman S., Moczydłowska M., and Grey K. 2006. Neoproterozoic (Ediacaran) diversification of acritarchs-A new record from the Murnaroo 1 drill core, eastern Officer Basin, Australia. Review of Palaeobotany and Palynology 139:17-39.

Yuan X. and Hofmann H. J. 1998. New microfossils from the Neoproterozoic (Sinian) Doushantuo Formation, Wengan, Guizhou Province, southwestern China. Alcheringa 22:189222.

Zhang Y., Leiming Y., Xiao S., and Knoll A. H. 1998. Permineralized fossils from the terminal Proterozoic Doushantuo Formation, South China. Paleontological Society Memoir 50. 52 p. 